\title{
IDENTITAS NASIONAL DALAM BUKU TEKS PELAJARAN SEJARAH SMA
}

\author{
M. Maman Sumaludin \\ SMA Pasundan 2 Bandung \\ mmamansumaludin@gmail.com
}

\begin{abstract}
This article discusses about national identity in history subject textbook for senior high school level. History subject textbook is one of the important media in history learning process, which is used as mandatory book as a tool to achieve the objectives of education. The elaborated materials inside the books are composed by the government, and contains ideology related ti national identity. National identity is distinct characteristics that only had by a nation. Fairclough's critical discourse analysis method is used to analyze the national identity points in the content of history subject textbook.
\end{abstract}

Abstrak: $\quad$ Artikel ini membahas wacana identitas nasional dalam buku teks pelajaran sejarah Sekolah Menengah Atas (SMA). Buku teks pelajaran sejarah merupakan salah satu media terpenting dalam proses pembelajaran sejarah di kelas, yang dijadikan buku wajib guna mencapai tujuan pendidikan. Materi yang diuraikan dalam buku teks berkaitan dengan kurikulum yang disusun oleh pemerintah. Implikasi buku teks terutama mata pelajaran sejarah dipengaruhi oleh idiologi yang dianut oleh negara, termasuk dalam penentuan materi yang sesuai dengn kurikulum yang disusun oleh negara, di mana ideologi yang dianut tersebut erat kaitannya dengan identitas nasional. Identitas nasional yang dimaksud adalah suatu jati diri yang khas dimiliki oleh suatu bangsa dan tidak dimiliki oleh bangsa yang lain. Metode yang digunakan untuk mengetahui wacana identitas nasional pada buku teks dengan menggunakan analisis wacana kritis Fairclough

Kata Kunci: $\quad$ identitas nasional, buku teks pelajaran sejarah

\section{PENDAHULUAN}

Penyajian buku teks memiliki keterkaitan signifikasi dengan tujuan pembelajaran. Salah satu aspek penting penyajian buku teks adalah bagaimana penulisannya. Model dan pendekatan yang dipakai dalam penulisan buku teks akan berkaitan dengan materi dan tujuan dari pembelajaran mata pelajaran tersebut. Pelajaran sejarah merupakan salah satu mata pelajaran yang memiliki perhatian terhadap pentingnya penulisan. Aspek penulisan dalam sejarah amatlah penting, sebab penulisan memberikan suatu gambaran bagaimana suatu suatu peristiwa itu dikonstruksikan dan dipahami. Konstruksi dan pemahaman terhadap peristiwa yang ditulis dalam buku teks pelajaran harus berkaitan dengan tujuan pembelajaran (Mulyana dan Darmiasti, 2009: 79).

Penulisan buku teks pelajaran sejarah untuk pendidikan di sekolah pada hakekatnya merupakan bagian dari perkembangan historiografi di Indonesia. Kesadaran untuk menulis buku sejarah sudah ada sejak awal kemerdekaan. Pada awal kemerdekaan buku-buku teks yang diterbitkan oleh pemerintah maupun swasta masih bersifat Nederlandosentrisme. Namun dalam perkembangannya beralih ke Indonesiasentris, mengingat kebutuhan pendidikan Indonesia saat itu adalah pembentukan kepribadian bangsa. Dengan demikian, perkembangan penulisan buku teks sejarah tidak terlepas dari jiwa zaman yang menandainya.

Pelajaran sejarah merupakan mata pelajaran yang tujuannya memiliki kaitan dengan pembentukan watak bangsa. Tujuan tersebut membuat tujuan pelajaran sejarah akan berkaitan dengan idiologi politik kenegaraan. Negara memiliki kewajiban membentuk watak kebangsaan yang dilakukan melalui pendidikan, salah satunya dengan mata pelajaran sejarah melalui buku teks sejarah. Kewajiban negara tersebut diimplementasikan melalui kebijakan pendidikan melalui kurikulum. Buku teks pelajaran pada hakikatnya merupakan penjabaran isi kurikulum secara operasional (Sitepu, 2012: 27). Dengan demikian tujuan pembelajaran sejarah menjadi idiologis untuk membentuk kepribadian dan watak bangsa, termasuk memperkuat identitas nasional didalamnya.

Buku sejarah merupakan bentuk praktek pewacanaan identitas nasional, teks-teks yang 
terkandung di dalamnya tentu saja mengakomodir pengetahuan-pengetahuan tertentu dan menyingkirkan sebagian lain (Heychael, 2012: 13). Begitu pula dengan buku teks sejarah sebagai bentuk praktek dari wacana identitas nasional yang dipengaruhi oleh idiologi kenegaraan melalui kebijakan pendidikan dan kurikulum. Dari perkembangan penulisan buku teks sejarah sejak awal kemerdekaan dari Nederlansentris ke Indonesiasentris, kemudian masa orde lama dengan semangat sosialisme dan anti kolonialismenya tidak memberi ruang pada pengetahuan demokrasi liberal, begitu pula dengan orde baru yang melarang ajaran komunisme dan marxisme. Lalu bagaimana dengan arah penulisan buku teks sejarah pada masa reformasi saat ini? Apakah wacana identitas nasional dalam buku teks sejarah dipengaruhi atau menyesuaikan jiwa zamannya (reformasi)?

Dalam artikel ini penulis mencoba melakukan analisis wacana terhadap penulisan buku teks sejarah SMA Kelas XI yang menggunakan Kurikulum 2013. Buku yang dianalisis merupakan buku terbitan pemerintah melalui Kementrian Pendidikan dan Kebudayaan Republik Indonesia tahun 2014. Fokus penelitian yang menyoalkan masalah identitas nasional yaitu pada bab mengenai 'Membangun Jati Diri Keindonesiaan'. Hal tersebut dipilih berkaitan dengan tema penulisan yaitu mengenai identitas nasional dalam buku teks sejarah.

\section{KAJIAN KONSEP}

\section{Identitas Nasional}

Identitas (identity) dalam kamus Oxford berasal dari bahasa Latin yaitu 'idem' atau sama dan dua makna dasar yaitu, pertama tentang kesamaan absolut dan yang kedua adalah konsep pembeda atau perbedaan yang menganggap adanya konsistensi dan kontinuitas (Jenkins dalam Heychles, 2012: 23). Identitas adalah soal apa yang kamu miliki secara bersama-sama dengan beberapa orang dan apa yang membedakan kamu dengan yang lainnya (Weeks dalam Barker, 2005: 221). Sementara itu kata 'nasional' merupakan identitas yang melekat pada kelompok-kelompok yang lebih besar yang diikat oleh kesamaan-kesamaan fisik, baik fisik seperti budaya, agama dan bahasa maupun nonfisik seperti cita-cita, keinginan dan tujuan. Himpunan kelompok inilah yang kemudian disebut dengan identitas bangsa atau identitas nasional yang pada akhirnya melahirkan tindakan kelompok yang diwujudkan dalam bentuk organisasi atau pergerakan-pergerakan yang diberi atribut-atribut nasional.

Dengan demikian dapat disimpulkan bahwa identitas nasional adalah suatu jati diri yang khas dimiliki oleh suatu bangsa dan tidak dimiliki oleh bangsa yang lain. Dalam hal ini, tidak hanya mengacu pada individu saja, akan tetapi berlaku juga pada suatu kelompok. Dengan kata lain, identitas nasional adalah kumpulan nilai-nilai budaya yang tumbuh dan berkembang dalam berbagai aspek kehidupan dari ratusan suku yang dihimpun dalam satu kesatuan Indonesia menjadi kebudayaan nasional dengan acuan pancasila dan Bhineka Tunggal Ika sebagai dasar dan arah pengembangannya.

Unsur-unsur identitas nasional merujuk pada bangsa yang majemuk. Kemajemukan itu merupakan gabungan unsur-unsur pembentuk identitas nasional yang meliputi suku bangsa, agama, kebudayaan dan bahasa. Dari unsur-unsur identitas nasional tersebut, dapat dirumuskan pembagiannya menjadi tiga bagian (Herdiawanto dan Hamadayama, 2010), yaitu: (1) Identitas Fundamental, yaitu pancasila sebagai falsafat bangsa, dasar negara dan ideologi negara. (2) Identitas Instrumental, yaitu berisi UUD 1945 dan tata perundang-undangannya. Dalam hal ini, bahasa yang digunakan bahasa Indonesia, bendera negara Indonesia, lambang negara Indonesia, lagu kebangsaan Indonesia yaitu Indonesia Raya. (3) Identitas Alamiah, yaitu meliputi negara kepulauan dan pluralisme dalam suku, budaya, bahasa dan agama serta kepercayaan

Wacana dipahami sebagai sebuah tindakan. Atau wacana juga dipahami sebagai bentuk interaksi. Jadi wacana merupakan sesuatu yang bertujuan, misalnya apakah untuk mempengaruhi, mendebat, membujuk, menyanggah, dan sebagainya. Wacana juga merupakan sesuatu yang diekspresikan secara sadar dan terkontrol.

\section{Buku Teks Pelajaran Sejarah Kurikulum 2013}

Buku teks pelajaran merupakan salah satu media terpenting dalam mencapai tujuan pembelajaran di sekolah. Menurut Permendiknas HISTORIA: Jurnal Pendidik dan Peneliti Sejarah, p-issn:2620-4789 | e-issn:2615-7993 
Nomor 2 Tahun 2008 bahwa buku teks pelajaran pendidikan dasar, menengah dan perguruan tinggi yang selanjutnya disebut buku teks adalah buku acuan wajib untuk digunakan di satuan pendidikan dasar dan menengah atau perguruan tinggi yang memuat materi pembelajaran dalam rangka peningkatan keimanan, ketakwaan, akhlak mulia, dan kepribadian, penguasaan ilmu pengetahuan dan teknologi, peningkatan kepekaan dan kemampuan estetis, peningkatan kemampuan kinestetis dan kesehatan yang disusun berdasarkan standar nasional pendidikan (Sitepu, 2012: 17). Pengertian tersebut, menentukan kedudukan buku teks pelajaran sebagai buku acuan wajib dalam proses pembelajaran disekolah, isi buku teks pelajaran memuat materi pembelajaran serta tujuan buku teks, yaitu mengacu kepada tujuan pendidikan nasional, serta penyusunannya mengikuti standar pendidikan nasional.

Dilihat dari isi dan penyajiannya, buku teks pelajaran berfungsi sebagai pedoman manual bagi siswa dalam belajar dan bagi guru dalam membelajarkan siswa untuk bidang studi tertentu. adapun fungsi buku teks pelajaran bagi siswa dan guru yaitu:

"Pedoman belajar bagi siswa berarti siswa menggunakannya sebagai acuan utama dalam: (1) memepersiapkan diri secara individu atau kelompok sebelum kegiatan belajar di kelas; (2) berinteraksi dalam proses pembelajaran dikelas; (3) mengerjakan tugas-tugas yang diberikan guru; dan (4) mempersiapkan diri untuk tes atau ujian formatif dan sumatif. Bagi guru, buku teks pelajaran digunakan sebagai acuan dalam: (1) membuat desain pembelajaran; (2) mempersiapkan sumber-sumber belajar lain; (3) mengembangkan bahan ajar yang kontekstual; (4) memberikan tugas; dan (5) menyusun bahan evaluasi” (Sitepu, 2012: 21)

Oleh karena kedudukan dan fungsi buku teks pelajaran seperti yang telah diuraikan, salah satu kebijakan pemerintah Indonesia dalam pembangunan pendidikan nasional adalah dengan mengadakan buku teks pelajaran.

Seperti halnya buku teks pelajaran lain, buku teks pelajaran sejarah memiliki keududukan dan fungsi bagi siswa maupun guru, terlebih lagi pelajaran sejarah memiliki fungsi yang strategis dalam pembentukan watak dan kepribadian bangsa. Helius Sjamsuddin dalam artikelnya (2000) menulis tentang kriteria dan permasalahan penulisan buku teks sejarah. Menurut pendapatnya ada enam kriteria yang harus dipenuhi dalam penulisan buku teks sejarah, yaitu:

“(1) Substansi faktual yang harus dipertangungjawabkan; (2) Penafsiran dan atau penjelasan; (3) Penyajian dan retorika yang harus sesuai dengan teori psikologi perkembangan; (4) Pengenalan konsepkonsep sejarah (Indonesia dan Umum) perlu menggunakan kriteria; (5) Buku teks pelajaran sejarah secara teknis-konseptual mengikuti GBPP (kurikulum); (6) kelengkapan ilustrasi, gambar, foto, peta-peta sejarah dalam setting dan lay out yang informatif dan naratif" (Sjamsuddin, 2000).

Selanjutnya, hal yang menjadi masalah terhadap kualitas penulisan buku teks pelajaran sejarah menurut pendapat Helius Sjamsuddin adalah terjadi tarik-menarik antara kebutuhan untuk memenuhi tuntutan pendidikan (akademik) di satu pihak dengan tuntutan keuntungan dari penerbit-penerbit di lain pihak. Tarik-menarik tersebut terkadang membuat penulis buku harus bekerja cepat karena tuntutan penerbit yang ingin cepat menjual bukunya. Bahkan di lapangan terjadi kompetisi antar penerbit dalam hal memasarkan buku terbitannya.

Menurut S. Hamid Hasan (2000) dalam artikelnya menulis tentang buku teks pelajaran sejarah dalam kaitannya dengan kurikulum, bahwa kurikulum selalu mengalami perkembangan sesuai dengan tantangan zaman, bagaimanakah buku teks pelajaran sejarah mampu menyesuaikan dengan perkembangan zaman. Kurikulum merupakan acuan utama dalam menulis buku teks sejarah. Menurut Sitepu (2012: 62) bahwa sasaran, tujuan, materi/bahan dan metode penyajian materi/bahan buku teks pelajaran merupakan unsur-unsur harus seuai dengan yang terdapat dalam kurikulum. Sasaran utama pembaca dan pengguna buku teks pelajaran adalah siswa dan guru. Tujuannya harus diselaraskan dengan tujuan pendidikan nasional dan Kurikulum 2013. Materi atau bahan ajar yang 
ditulis dalam bahan buku teks pelajaran ditentukan dengan menganalisis KI dan KD mata pelajaran mengacu pada kompetnsi mata pelajaran yang bersangkutan.

\section{METODE}

Metode yang digunakan dalam mengkaji buku teks pelajaran sejarah ini adalah metode analisis wacana kritis Fairclough. Ciri khas dari metode analisis wacana kritis adalah bahwa hubungan antara praktik sosial dan teks diperantarai oleh prkatik wacana; bagaimana sebuah teks diproduksi dan dinterpretasi, dalam pengertian apa praktik wacana dan akidah dibuat, dari apa order of discourse dan bagaimana mereka diaktualisasikan secara bersamaan. Proses ini pada akhirnya dipengaruhi oleh praktik sosial termasuk hubungan dengan hegemoni yang terkaji (Fairclough, dalam Heychael, 2012: 54). Dalam analisis wacana dikenal adanya tiga sudut pandang mengenai bahasa (Eriyanto, 2006: 4-6). Pandangan pertama, bahasa dilihat sebagai jembatan antara manusia dengan objek di luar dirinya. Jadi analisis wacana digunakan untuk menggambarkan tata aturan kalimat, bahasa, dan pengertian bersama. Wacana diukur dengan pertimbangan kebenaran/ketidakbenaran menurut sintaksis dan semantik. Pandangan kedua, subjek sebagai faktor sentral dalam kegiatan wacana serta hubungan-hubungan sosialnya. Jadi analisis wacana dimaksudkan sebagai suatu analisis untuk membongkar maksud-maksud dan makna-makna tertentu. Pandangan ketiga, bahasa dipahami sebagai representasi yang berperan dalam membetuk subjek tertentu,tema-tema wacana tertentu, maupun strategi-strategi di dalamnya. Jadi analisis wacana dipakai untuk membongkar kuasa yang ada dalam setiap proses bahasa. Analisis wacana ini dikenal dengan nama analisis wacana kritis karena menggunakan perspektif kritis.

Mengutip apa yang dipaparkan dalam buku analisis wacana (Eriyanto, 2006), berikut ini merupakan hal-hal yang mencirikan sebuah analisis wacana kritis.

1. Tindakan

Wacana dipahami sebagai sebuah tindakan. Atau wacana juga dipahami sebagai bentuk interaksi.
Jadi wacana merupakan sesuatu yang bertujuan, misalnya apakah untuk mempengaruhi, mendebat, membujuk, menyanggah, dan sebagainya. Wacana juga merupakan sesuatu yang diekspresikan secara sadar dan terkontrol.

\section{Konteks}

Mengacu pada pendapat Guy Cook, dalam analisis wacana juga memeriksa konteks dari komunikasi seperti siapa yang mengkomunikasikan dengan siapa dan mengapa; dalam jenis khalayak dan situasi apa; melalui medium apa; bagaimana perbedaan tipe dari perkembangan komunikasi; dan hubungan untuk masing-masing pihak. Sehubungan dengan konteks dalam wacana, Fillmore mengungkapkan betapa pentingnya peran konteks untuk menentukan makna suatu ujaran, bila konteks berubah maka berubah pula maknanya. Sementara itu Syaf'ie (dalam Lubis, 1993: 58) membedakan konteks dalam pemakaian bahasa menjadi empat macam: (1) konteks fisik yang meliputi tempat terjadinya pemakaian bahasa dalam suatu komunikasi, objek yang disajikan dalam peristiwa komunikasi itu, dan tindakan atau perilaku dari para peran dalam komunikasi itu; (2) konteks epistemis atau latar belakang pengetahuan yang sama-sama diketahui oleh pembicara maupun pendengar; (3) konteks linguistik yang terdiri dari kalimat-kalimat atau tuturan-tuturan yang mendahului satu kalimat atau tuturan tertentu dalam peristiwa komunikasi; dan (4) konteks sosial yaitu relasi sosial dan latar setting yang melengkapi hubungan antara pembicara (penutur) dengan pendengar.

3. Historis

Untuk dapat memahami suatu wacana teks maka dapat dilakukan dengan memberikan konteks historis di mana teks itu diciptakan. Oleh karena itu pada saat menganalisis perlu dimengerti mengapa wacana yang berkembang atau dikembangkan seperti itu, mengapa bahasa yang dipakai seperti itu, dan sebagainya.

\section{Kekuasaan}

Semua wacana yang muncul dalam bentuk teks, percakapan, atau apapun dipandang sebagai bentuk pertarungan kekuasaan. Konsep kekuasaan adalah salah satu kunci hubungan antara wacana dan masyarakat. Hubungan antara kekuasaan dan 
wacana dapat dilihat dari apa yang dinamakan kontrol. Kontrol dalam suatu wacana dapat berupa kontrol atas konteks, dan kontrol terhadap struktur wacana. Kontrol atas konteks misalnya dapat dilihat dari siapa yang boleh atau harus bicara sedangkan posisi yang lain sebagai pendengar atau yang mengiyakan. Sedangkan kontrol terhadap struktur wacana dapat dilihat dari seseorang yang memiliki kekuasaan lebih besar dapat menentukan bagian mana yang perlu ditampilkan dan bagian mana yang tidak serta bagaimana ia harus ditampilkan.

5. Ideologi

Wacana digunakan sebagai alat oleh kelompok dominan untuk mempersuasi dan mengkomunikasikan kekuasaan yang mereka miliki agar terlihat absah dan benar dimata khalayak. Suatu teks, percakapan dan lainnya adalah bentuk dari praktik ideologi tertentu. Menurut teori-teori ideologi dikatakan bahwa ideologi dibangun oleh kelompok yang dominan dengan tujuan untuk mereproduksi dan melegitimasi dominasi mereka. Strategi utamanya adalah dengan membangun kesadaran khalayak bahwa dominasi itu dapat diterima secara taken for granted.

\section{PEMBAHASAN}

Analisis isi dan wacana identitas nasional dalam buku teks pelajaran sejarah SMA yang difokuskan pada materi kelas XI bab 3 mengenai 'Membangun Jati diri Keindonesiaan' yang terdiri atas 3 sub bab yaitu: 'Menghayati Tumbuhnya Ruh Kebangsaan dan Nasionalisme', 'Menganalisis Perjuangan Organisasi Pergerakan Kebangsaan', dan 'Menganalisis Proses Penguatan Jati diri Bangsa'. Sebagaimana tertera dalam bab yang dibahas, uraian dimaksudakan untuk menjelaskan membangun jati diri keIndonesiaan, dalam kerangka analisis wacana kritis pada sub bab menghayati tumbuhnya ruh kebangsaan dan nasionalsime. Seperti pada wacana teks berikut.

"Adanya pendidikan gaya Barat itu membuka peluang bagi mobilitas sosial masyarakat di tanah Hindia/Indonesia. Pengaruh pendidikan Barat itu pula yang kemudian memunculkan sekelompok kecil intelektual bumiputra yang memunculkan kesadaran, bahwa rakyat bumiputra harus mampu bersaing dengan bangsa-bangsa lain untuk mencapai kemajuan.
Golongan intelektual bumiputra itu disebut "priyayi baru" yang sebagian besar adalah guru dan jurnalis di kota-kota. Pendidikan dan pers itu pula menjadi untuk menyalurkan ide-ide dan pemikiran yang ingin membawa kemajuan, dan pembebasan bangsa dari segala bentuk penindasan dari kolonialisme Belanda. Mereka tidak memandang Jawa, Sunda, Minangkabau, Ambon, atau apa pun karena mereka adalah bumiputra. Pengalaman yang mereka peroleh di sekolah dan dalam kehidupan setelah lulus sangatlah berbeda dengan generasi orang tua mereka. Para kaum muda terpelajar inilah yang kemudian membentuk kesadaran "nasional" sebagai bumiputra di Hindia, dan bergerak bersama "bangsa-bangsa" lain dalam garis waktu yang tidak terhingga menuju modernitas, suatu dunia yang memberi makna baru bagi kaum pelajar terdidik saat itu" (Sadirman dan Lestrainingsih, 2014: 147).

Melalui teks di atas, kita melihat masalah diasumsikan terjadi karena adanya penjajahan dan keterbelakangan bangsa Indonesia. Lahirnya kelas menengah yang dihaslikan oleh pendidikan kolonial, kemudian berupaya mengkoreksi keadaan ini. Meskipun tidak semua bangsa Indonesia memiliki akses pada pendidikan barat dan memiliki kesadaran yang sama dengan mereka. Namun mereka yang lebih terdidik tidak hanya mementingkan dirinya sendiri, mereka berupaya menyebarkan pengetahuan yang mereka miliki dengan membentuk sekolah-sekolah pribumi. Kesadaran nasional sebagai dampak dari politik etis digunakan sebaik-baiknya tidak hanya oleh golongan terpelajar, namun golongan semua lapisan masyarakat dari seluruh daerah, tanpa mengenal suku, agama, dan pekerjaan. Dari sinilah jati diri keIndonensiaan mulai dibentuk dan memperlihatkan identitas nasional sebagai suatu bangsa yang bernasib sama.

Sebagai kelanjutan, sub bab selanjutnya yaitu mengenai menganalisis perjuangan organisasi pergerakan kebangsaan. Pada awal abad ke-20, di Nusantara muncul berbagai kelompok dan organisasi yang memiliki konsep nasionalisme, seperti Sarekat Dagang Islam (kemudian menjadi Sarekat Islam), Budi Utomo (BU), Jong Java, Jong 
Celebes, Jong Minahasan, Jong Sumatranen Bond, dan lainnya. Munculnya organisasi-organisasi itu mendanai fase perubahan perlawanan terhadap pemerintah kolonial Belanda. Kalau sebelumnya berupa perlawanan fisik kedaerahan menjadi pergerakan nasional yang bersifat modern. Organisasi-organisasi itu mengusung tujuan yang sama, yakni untuk lepas dari penjajahan.

"Para tokoh pendiri BU berpendapat bahwa untukmendapatkankemajuan, makapendidikan dan pengajaran harus menjadi perhatian utama. Organisasi itu mempunyai corak sebagai organisasi modern, yaitu mempunyai pimpinan, ideologi dan keanggotaan yang jelas. Corak baru itu kemudian diikuti oleh organisasiorganisasi lain yang membawa pada perubahan sosial-politik" (Sadirman dan Lestringingsih, 2014, hal.158).

Dari teks di atas, jelas bahwa Budi Oetomo sebagai salah satu organisasi pergerakan pertama yang mengutamakan pendidikan sebagai alat pembebasan dari penjajahan, selain bentuk organisasinya yang lebih modern sehingga menjadi contoh bagi organisasi lain. Namun pada masa ini organisasi-organisasi masih berjalan sendirisendiri. Hingga akhirnya tiba pada waktunya seluruh pemuda dari berbagai daerah menyatukan visi dalam sebuah kongres, yang dilatar belakangi oleh kesamaan nasib.

Mengenai hal tersebut dijelaskan dalam sub bab terakhir yaitu mengenai 'Menganalaisis Proses Penguatan Jati Diri'. Pada sub bab menjelaskan mengenai perjalanan sumpah pemuda sampai pasca sumpah pemuda dengan berdirinya partai-partai politik. Sumpah pemuda dalam narasi buku sejarah maupun buku teks sejarah adalah kelanjutan dari upaya perjuangan non-kooperasi yang dimualai dengan upaya membangun kesadaran bersama sebagai suatu bangsa. Untuk sampai sana perlu adanya pengorbanan demi meninggalkan politik sectarian dan kesukuan. Berangkat dari perbedaanperbedaan suku, agama, aliran politik, bangsa Indonesia bersatu dibawah sebuah bendera yang sama dan gagasan yang sama mengenai sebuah negara merdeka. Kesadaran kesukuan merupakan awal dari suatu kesadaran yang lebih besar dan luhur yaitu nasionalisme Indonesia. Langkah itu pertama- tama dimulai dengan perkumpulan yang dilakukan oleh beberapa oragnisasi kelompok etnis seperti Jong Ambon, Jong Java, Jong Minahasa, dan Jong Sumtranen. Hal ini pula dimungkinkan berkumpul berbagai etnis dalam satu lembaga pendidikan yang sama, berkenal satu sama lain lewat berbagai medium seperti pendidikan dan pergerakan nasional pada akhirnya mendorong pada kesadaran nasional. Cita-cita tersebut mengemuka lewat kongres pemuda pertama yang isinya menyerukan untuk persatuan berbagai organisasi pemuda dalam satu wadah, dan untuk itu disiapkan kongres pemuda dua. Pada kongres itu juga M. Yamin mulai mengusulkan bahasa Melayu sebagai bahasa nasional. Dari sini kita melihat bahasa sebagai alat pemersatu.

"Keputusan pemuda-pemudi itu kemudian dikenal dengan Sumpah Pemuda, pada saat itu pula dikumandangkannya lagu Indonesia Raya ciptaan Wage Rudolf Supratman dan bendera Merah Putih digunakan sebagai bendera Pusaka Bangsa Indonesia. Peristiwa Sumpah Pemuda, 28 Oktober 1928 itu merupakan puncak pergerakan nasional. Karena itulah kita memperingatinya sebagai peristiwa bersejarah yang diperingati setiap tahun hingga saat ini sebagai hari besar nasional. Putusan kongres itu menjiwa setiap perkumpulan pemuda di Indonesia di kemudian hari" (Sadirman dan Lestariningsih, 2014: 187)

Kongres pemuda kedua atau yang dikenal dengan Sumpah Pemuda merupakan puncak dari pencapaian kultur dari nasionaslisme Indonesia. Di mana akhirnya bahasa persatuan dan bahsan nasional diteguhkan sebagai bagian dari identitas kebangsaan Indonesia. Selain itu, bendera merah putih, dan lagu kebangsaan Indonesia Raya juga menjadi bagian dari simbol nasional. Peristiwa inilah yang menjadi tonggak tegaknya identitas nasional bangsa Indonesia sampai saat ini hingga nanti.

Dari beberapa contoh wacana dalam buku teks pelajaran sejarah yang telah dipaparkan, penulis buku ini melalui tulisannya berusaha untuk memberikan wawasan kebangsaan dan kesadaran sejarah dengan mengungkapkan fakta-fakta sejarah terbentuknya sebuah bangsa sebagai identitas

HISTORIA: Jurnal Pendidik dan Peneliti Sejarah, p-issn:2620-4789 | e-issn:2615-7993 
nasional. Hal ini berkaitan dengan idiologi politik kenegaraan, di mana Negara mempengaruhi semua sudut kehidupan, terutama pendidikan sebagai alat legitimasi kekuasaan sebuah pemerintahan di suatu negara. Karena Negara memiliki kewajiban membentuk watak kebangsaan yang dilakukan melalui pendidikan, salah satunya dengan mata pelajaran sejarah melalui buku teks sejarah.

Kewajiban negara tersebut diimplementasikan melalui kebijakan pendidikan melalui kurikulum. Buku teks pelajaran pada hakikatnya merupakan penjabaran isi kurikulum secara operasional. Seperti halnya buku teks sejarah sebagai bentuk praktek dari wacana identitas nasional yang dipengaruhi oleh idiologi kenegaraan melalui kebijakan pendidikan dan kurikulum. Oleh karena itu, tujuan pembelajaran sejarah menjadi idiologis untuk membentuk kepribadian dan watak bangsa, termasuk memperkuat identitas nasional didalamnya.

\section{SIMPULAN}

Identitas nasional hingga saat ini, sebagai mana dapat dilihat dalam buku teks pelajaran sejarah, masih juga merupakan kelanjutan dari bentuk-bentuk kuasa/pengetahuan yang bercorak kolonial, meskipun penulisan buku teks dimasa kemerdekaan bersifat Indonesiasentris tidak lagi Nederlandsentris. Kuasa/pengetahuan dalam pengertian ini, tentu saja bukan sekdar persoalan dalam proses seperti apa bangsa Indonesia menjadi atau golongan mana saja yang ikut melahirkannya? Melainkan lebih dari pada itu, kolonialisme dalam upaya perumusan identitas nasional justru terjadi pada tataran epistemolgi.

Sejarah dipandang sebagai ilmu yang dapat merekonstruksi masa lalu yang objektif. Di mana negara bangsa, diandaikan sebagai kenyataan sejarah revolusi umat manusia, dari pra modern ke masyarakat modern. Sejarah dilihat sebagai gerak lurus. Absen krtitik terhadap pola pikir semacam ini dalam historiografi nasioanl, pada akhirnya menempatkan nilai-nilai yang dikategorikan sebagai nonmodern, sebagai kuno dan bagian dari masa lalu yang mesti ditingalkan. Pandangan semacam ini yang beroprasi dalam bab-bab buku sejarah, di mana Indonesia yang berbangsa-bangsa diturunkan derajatnya menjadi suku bangsa Sunda, Jawa, Melayu dan lainnya. Bahkan nilai kesukuan masih juga dicurigai sebagi nilai-nilai yang dapat menghambat persatuan nasional. Corak pandang sejarah semacam ini tidak mungkin tidak lahir dari sejarah yang sentralistis. Sejarah nasional dengan kata lain adalah sejarah negara. Sementara rakyat adalah objek sejarah dan negara (para elit) subjek yang menulis sejarah tidaklah mengherankan bila sejarah nasional lebih berpusat pada pahlawanpahlawan besar, tanpa membicarakan kehidupan orang kebanyakan.

Begitu halnya dengan penulisan buku teks pelajaran sejarah, pengaruh pemerintah begitu kuat dalam hal idiologisasi penulisan buku teks, sebagai wujud kewajiban negara dalam upaya membentuk watak dan kepribadian bangsa serta memperkokoh identitas nasional melalui pendidikan. Kebijakan pendidikan dan kurikulum menjadi alat untuk memuluskan tujuan negara dalam menanamkan idiologi negara. Identitas nasional adalah ciri dari jatidiri bangsa Indonesia yang membedakan bangsa Indonesia dengan bangsa lain di dunia

\section{REFERENSI}

Barker, C. (2000). Cultural Study: Theory and Practice. London-Thousand Oaks-New Delhi: Sage Publication.

Eriyanto. (2006). Analisis Wacana Pengantar Analisis Teks Media. Yogyakarta: LKIS.

Hasan, S. H. (2000). Kurikulum dan Buku Teks Sejarah. Historia Jurnal Pendidikan Sejarah FPIPS UPI, 1 (1).

Heychael, M. (2012). Identitas Nasional dalam Buku Sejarah Untuk Sekolah Menengah Pertama (SMP). Program Studi Pascasarjana Kekhususan Ilmu Komunikasi Fakultas Imu Sosial dan Ilmu Politik Universitas Indonesia. Tidak Diterbitkan.

Herdiawanto, H. dan Hamdayama, J. (2010). Cerdas, Kritis, Dan Aktif Berwarganegara

(Pendidikan Kewarganegaraan untuk Perguruan Tinggi). Jakarta: Erlangga.

Lubis, A.H.H. (1993). Analisis Wacana Pragmatis. Bandung: Angkasa. 
Mulyana, A. dan Darmiasti. (2009). Historiografi Di Indonesia: Dari Magis-Religius Hingga Strukturalis. Bandung: Refika Aditama.

Sadirman A.M. dan Lestringsih, A.D (Kontributor). (2014). Sejarah Indonesia untuk SMA/MA SMK/MAK Kelas X1 Semester 1. Jakarta: Kemendikbud.
Sitepu, B.P. (2012). Penulisan Buku Teks Pelajaran. Bandung: Remaja Rosdakarya.

Sjamsuddin, H. (2000). Penulisan Buku Teks Sejarah: Kriteria dan Permasalahannya. Historia Jurnal Pendidikan Sejarah FPIPS UPI, 1(1). 